\title{
The British Academy Brian Barry Prize Essay: Representing the Future: The Interests of Future Persons in Representative Democracy
}

\author{
Andre Santos Campos* \\ Faculty of Social Sciences and Humanities, Nova University of Lisbon, Portugal \\ *Corresponding author. E-mail: andrecampos@fcsh.unl.pt
}

(Received 19 January 2019; revised 1 July 2019; accepted 4 December 2019; first published online 31 January 2020)

\begin{abstract}
As a reaction against contemporary democracy's inherent short-sightedness in solving problems that are likely to affect distant future generations, there has been a recent increase in proposals for different kinds of democratic representation of future persons. This article shows that even though there can be no such thing as political representation of future persons, the relevant affected interests of the as-yet unborn can still be taken into consideration in political decision making. This aim is achieved by focusing on the political representation of children as special cases of semi-future members of the class of the represented.
\end{abstract}

Keywords: political representation; future persons; representative democracy; future generations; semi-future constituency

One of the greatest challenges faced by contemporary political societies is overcoming the tendency in representative democracies to engage in short-termism. Problems such as the amount of public debt that is fair to incur, the funding of future pensions, youth unemployment, poverty and exclusion, and, most forcefully, climate change, seem to require political solutions that are perceptively longsighted. However, privileging the future in terms of producing policies that are responsive to the interests of persons still unborn cannot imply a disregard for the interests of the current population. Otherwise, long-termism would be anti-democratic in the sense that the interests of the current addressees of government would be excluded from the political process. In order to counter severe long-term problems, contemporary democracies must commit to the long run in a way that strikes a balance between those who participate in representative democracies and those whose interests will be affected by current decisions in the future.

In the search for this balance, the future has entered the equation in debates concerning the democratic politics of inclusion. More specifically, there has been a resurgence of proposals to include the future in representative processes based on the idea that future persons should 'have a voice today' (Gosseries 2008a, 34). However, what kind of voice - and who should express it - are contentious issues. Such proposals tend to focus on different, albeit connected, aspects of representative democracies. Some focus on the quality of the representatives. According to this line of thinking, what brings forth genuine representation is the nature of the representative office as such, and the characteristics of its occupants. Future perspectives can therefore be represented by establishing future-oriented institutions such as ombudsmen for future generations (Agius and Busuttil 1998; Beckman and Uggla 2016; Göpel 2012; Slaughter 1994; Weiss 1992) and special legislative chambers for the future (Bovenkerk 2015; Caney 2016; Mackenzie 2016; Read 2012; Stein 1998). But those future perspectives can also be represented by reforming current institutions in order to make them future beneficial, such as establishing parliamentary quotas for 
future generations (Ekeli 2005; Ekeli 2009; Kavka and Warren 1983), for experts on environmental issues (Dobson 1996), or for younger representatives as proxies for future persons (Bidadanure 2016).

Other kinds of proposals focus on the nature and quality of the constituency, for instance by enlarging the franchise to children and young adults, who would be able to exercise their right to vote directly (Cook 2013; Umbers 2018) or via their parents (Parijs 1998; Ringen 1997; Wall 2014). Child enfranchisement would allow young voters to function as proxies for future persons (Hinrichs 2002, 51).

A third category of proposals focuses on the operation of representative government. In such cases, the mere existence of a particular office or official is insufficient to produce representation. What matters is that the actions inherent in the exercise of government purport to be representative of far-future interests. Examples can be found in the claim to have present surrogates to vindicate the interests of future persons (Ekeli 2006; Karnein 2016) or to include future generations in the communicative processes of deliberative democracies (Beyleveld, Düwell and Spahn 2015; Eckersley 2011; Goodin 1996; Niemeyer and Jennstål 2016). ${ }^{1}$

Critics of the association between political representation and as-yet unborn persons argue that the interests of future generations could find their way onto the political agenda more effectively by employing different normative concepts. The underlying intention here would be not to represent the interests of future persons as such, but rather to develop institutional constraints that would safeguard those interests in the future. This quasi-representative relationship would be more akin to trusteeship (Thompson 2010) or 'reflective paternalism' (Rose 2016a), which would require independent commissions or agencies - such as a higher chamber of parliament, for instance (Tonn and Hogan 2006) - that could protect the interests of future persons.

In the context of intergenerational justice, debates about democratic representation often reveal a tension between voicing the interests of present constituents and voicing the (possibly opposite) viewpoints of future persons. This gives rise to theoretical and practical difficulties concerning long-term problems, since the interests of present constituents are usually interpreted on a short-term basis, and traditional conceptions of political representation are unable to encompass the as-yet unborn. This article shows that even though there is no such thing as the political representation of future persons, the as-yet unborn can still be included in democratic representative processes without having to appeal to alternative conceptions of representation such as surrogacy, guardianship, advocacy or authenticity. The key to achieving this aim is to incorporate children into the representative action - not by including them in the franchise but by recognizing that they are members of the class of the represented.

The article has two parts. First, it recalls some of the reasons why the concept of political representation and its many variants is inadequate with regard to future persons. Secondly, it demonstrates that representative democracies already contain the instruments to develop a 'longtermist' approach when they involve children in decision-making processes without necessarily enfranchising them. A combination of two arguments supports this claim: (1) the argument from the juridical all-affected-interests, according to which children are addressees of political norms and policies and (2) the argument from the semi-future constituency, according to which children's present interests have the same normative status as the interests they will share in the long run with future children. Both arguments are cumulative: the decisive second argument depends upon the soundness of the first. And neither of them can support the main claim without the other. In the end, it should be clear that the representation of interests that will be held by as-yet unborn persons does not necessarily require a high degree of creativity in designing new institutions for the future or reforming present institutions for the long run. All that is needed is an optimal operation of democratic representative government that considers the affected interests of all members of the class of the represented.

\footnotetext{
${ }^{1}$ For a Rawlsian-based critique, see Heyward (2008).
} 


\section{The difficulties of representing the future}

The notion of representation put forward in the classic works on the subject (Pitkin 1967; Urbinati 2006) typically involves, in the formalistic sense, authorization and accountability with regard to the persons whose interests are potentially affected by the actions of representatives. From the outset this constitutes a major obstacle to representing the far future, since the as-yet unborn are unable to hold present political institutions accountable or to authorize their decisions in time. However, the formalistic version of representation is not the only available model of inclusion in representative decision making. Representation can also be regarded in terms of the concurrence between the interests voiced by representatives and the actual interests of the represented, even if such a concurrence is to be assessed only after the fact, in which case a sympathetic validation by the relevant proto-constituency at some reasonable future time (Rehfeld 2006) or authenticity (Saward 2009) or surrogate accountability (Rubenstein 2007) seem like better criteria for determining representation than actual authorization.

Such accounts of political representation are concerned mostly with ascertaining the legitimacy of claims to representative action. In light of the available criteria for assessing claims to representation (authorization, presumed or actual; accountability; acceptance; authenticity; surrogate accountability; etc.), what is being assessed is whether those claims are legitimate as representative, in the sense of whether they are successful at being representative at all. Those accounts seem to assume that all de facto representation is necessarily legitimate representation, and vice versa. The notion of 'illegitimate representation' would be a contradiction, since true representation cannot exist without legitimacy. When applied to the intergenerational context, such accounts assume that there is such a thing as interests that will be held by persons in the future, the existence of which is independent of the representative process. These interests need only to be embodied in language expressed by those who claim to represent them in the present. The legitimacy criteria function as litmus tests for ascertaining whether the concurrence between interests and the claims to representative action is indeed representative.

However, the ambiguity inherent in the concept of representation complicates matters further. Representation is more than the mere coincidence of claims to representation and actual pre-existent interests in light of some normative criterion. It is also a performative notion that constitutes the entities participating in the representative process as well as their specific interests. The commonplace view that political representation connects two entities - one that exists without a proper organization and another that stands for, acts for and speaks for the former - is therefore mistaken. Representation is not simply constitutive of a representative that somehow impersonates and makes the represented present. It is also constitutive of the represented as such. The class of the represented is a social construction in the same sense as the class of the representatives (Lefort 1988; Urbinati and Warren 2008).

The litmus test for ascertaining actual representation does not consist of measuring the extent to which interests and claims to representative action coincide substantively with a preestablished criterion. Such an evaluation can be conducted to assess the legitimacy of a specific representative action. But at the performative level, what determines an actual representative action is whether claims to representation are constitutive of both the role of the representatives and of the actual persons qua represented. Representation does not simply amplify a voice that was not being heard; it creates it anew. It gives a voice to those who were otherwise silent and who acquire a political existence only because they now have a voice. But not just any voice, or the representatives' voice; the previously silent now have their own voice. The representative action is constitutive of their voice toward a third party and of their normative status toward the representatives who voice them. ${ }^{2}$ Regardless of how one considers the contents of the

\footnotetext{
${ }^{2}$ The question of whether political representation is defined as a three-way relationship between representatives, the represented and a third party (the interlocutor) rather than as a two-way relationship between representatives and the represented
} 
mandate, representation comprises a set of constitutive rules in which the representatives have certain duties toward the represented.

In actual authorization and accountability, the constitutive moment coincides with the granting of consent and/or repudiation. Representatives and the represented are from that moment reciprocally bound in a normative relationship in which the former have certain duties toward the latter. With regard to the distant future, the constitutive moment is harder to determine, since it involves a normative relationship with non-simultaneous correlative elements - one of which (the claim-right held by a future person) may never come to exist. ${ }^{3}$ In such cases of generational non-overlap, the constitutive moment is a creation of those who claim to be representatives, as if they became bound to an entity which they create themselves and who cannot exercise its claim-rights. In such a discretionary act of voicing, anything whatsoever could be included in the representative process (Goodin 2007, 55). Alternative hypotheses in favour of representatives or ombudspersons who are said to count as replacement rights-holders for future persons seem to be misunderstanding the nature of the representative relationship. They presume that the content of the representatives' mandate includes rights rather than duties, as well as the actualization of non-existents, when in fact representatives actualize diffuse claim-rights rather than actual persons (Campos 2019b, 631).

Political proxies or surrogates (Mansbridge 2003, 522-525; Rose 2016b; Saward 2009) who share certain characteristics with future persons or who advocate (Urbinati 2000) interests that may coincide with those of future persons often seem to be suitable instruments for surpassing these problems. However, strictly speaking, they can hardly be called representatives. Resemblance of characteristics or interests upheld is closer to what Hannah Pitkin called 'descriptive representation' (Pitkin 1967, 60-91) - that is, representativeness rather than representation. The act of mirroring characteristics or interests falls short of actual political inclusion. A school council, for instance, can be representative of several groups of persons involved in the school's activities (for example, teachers, students, parents, employees, community members, etc.) even though it does not necessarily represent the school itself, either as such or vis-à-vis third parties. There can be representativeness without representation, and vice versa. Moreover, 'surrogate representation', which in the context of intergenerational justice comes into view chiefly in the defence of parliamentary (youth or future) quotas (Karnein 2016), seems to mischaracterize what is distinctive about political representation - the fact that it includes in decision-making processes the actual (not simply similar) interests of those affected. Representatives are not supposed to be stakeholders themselves; nor are they necessarily expected to share personal characteristics or interests with those they represent. ${ }^{4}$

(Schmitt 2008,242) is peripheral to this discussion because any constitutive normative representation requires both kinds of relationships.

${ }^{3}$ This seems to be one of the possible consequences of the much-debated non-identity problem, which presents the following puzzle. Which particular future persons will exist depends on when their procreation takes place; but even if we could accurately predict that certain actions or policies would make future persons worse off, the fact remains that any persons born as a result of these actions or policies would not have been born at all if alternative actions or policies had been adopted. Consequently, assuming that such persons would have lives worth living, they cannot be harmed by those actions or policies (Parfit 1987, 351-79).

${ }^{4}$ Recent developments in debates favouring proxy representation acknowledge these complications and accept that it is a deficient model of representation compared to the formalistic model (Rose 2016b, 162). Rather than searching for (or expecting) some sort of ex post legitimacy (Saward 2009), authors such as Rose (2016b, 158) maintain that proxies are legitimized democratically by being authorized to participate in the present political-administrative system, but are still representatives of future persons in the sense that they are obligated to them. At the performative level, though, this seems very problematic because what constitutes proxies as representatives is the authorization attributed by the present political-administrative system. This authorization is what defines future persons as represented. It is only because the political-administrative system has rules of competence authorizing proxies to represent a third party that they are representatives in the first place. The reason they are obligated to favour what they think are the interests of future persons is that the political-administrative system contains rules binding them to it. They become legally obligated to being morally obligated to future persons. But what 
From the viewpoint of the franchise, proxies for future persons pose three further problems. Attributing voting rights to the youth only brings about additional difficulties. First, proposals to expand the franchise by lowering the minimum voting age still exclude a significant number of children from the political process insofar as voting requires specific (even if not particularly demanding) epistemic conditions. These proposals end up mitigating the exclusion of young adults from elections, but at the cost of endorsing the exclusion of a large segment of the population, such as infants.

One way to overcome such exclusions is to attribute voting rights to all children, which would be exercised by their parents. But this solution would entail a new set of puzzles: (1) in practice, enfranchising the young, and perhaps even disenfranchising the old (Parijs 1998), would result in votes cast only by middle-aged adults in a society, thereby concentrating presence in voting booths to fewer and fewer persons; (2) high fertility rates would translate into more rights exercised by a specific group of persons (for example, parents of large families); (3) parents would have to represent their children in voting, that is, to follow a duty to exercise a right on their behalf and in their interest, in what would seem like a double stage of representation; and (4) the unlikelihood that parents would consider their interests as parents differently from their children's interests as children would amount to a needless duplication of ballots (Hinrichs 2002).

The second problem introduced by proxies for future persons is that epistemic obstacles are not easy to overcome. If it is already doubtful that representatives can reach and express a reasonable degree of understanding and prediction of the future, especially distant futures, at the level of the franchise such reasonableness seems even less obvious. Young voters are not guaranteed to vote for representatives who would promote policies to safeguard their long-term interests. Indeed, there is considerable evidence that young adults are more prone to think in terms of urgency (Carstensen, Isaacowitz and Charles 1999) and to engage in higher levels of risk taking than older adults (Palsson 1996). ${ }^{5}$ Within such a framework, even scepticism regarding young adults' ability to determine which candidates' proposals would promote their own interests seems adequate. Once more, having their parents vote for them would overcome these problems, but at the cost of falling into the aforementioned traps.

Thirdly, proxy voting introduces practical difficulties. Why would child voters be proxies for future persons rather than for infants? And, as proxies, would their votes be counted as revealing their own preferences, or those of the group for which they serve as proxies? In either case, how would their votes be given the same value as the votes of adults?

Moreover, with regard to the representatives and the franchise, it seems impossible to represent existing and future people on equal terms, since the identity and numbers of the latter are unknown. Even if actual present persons and possible future persons could be considered on an equal footing, the indefinite extension of the future across several generations would provide a supermajority to those as-yet unborn, thus risking overinclusion (Attfield 2003, 130). Equality of treatment in representation between present and future persons thus seems unfeasible. Adopting traditional schemes of representation for the future would produce institutions in which not all representatives would be regarded as equally legitimate. Since the concept of political representation aspires to involve the represented as equals in the political process, the inclusion of future persons would seem detrimental, rather than beneficial, to the representative action. The notions of trusteeship and guardianship seem to solve this puzzle because they do not purport to strive for equality. Trustees and guardians, who are frequently thought of as protecting and defending those who are not yet (or no longer) capable of acting as normative agents, occupy a superior standing

makes them representatives is the primary legal obligation rather than the moral one (which is then a secondary legal obligation). If representation is involved, representatives seem to represent the political-administrative system's present interests by having officials who help future interests find their way into the political debate, rather than simply representing future persons as proxies.

${ }^{5}$ See also, for instance, Green et al. (1999) and Steinberg et al. (2009). 
over them; the same can be said of advocates, who are typically thought of as promoting certain agendas. One may wonder whether there is any representative action in such cases, given that the notion of representation normatively requires that representatives abstain from any idea of alleged superiority or one-sided beneficence and embrace the task of giving voice to those who, were they present, could and would speak for themselves.

\section{Representing the future}

The political representation of future persons seems conceptually problematic given that such persons cannot fully acquire in the present the status of the represented. There are surely other ways of lobbying in favour of the interests of future generations, and there have been several experiences and proposals at the level of institutional design to that effect. ${ }^{6}$ However, the interests of the as-yet unborn can still be included in representative processes without requiring the actual political representation of future persons. The hypothesis explored below assesses the feasibility of including children in representative action in two steps. First, it develops the thesis that a juridical interpretation of the all-affected-interests principle requires the inclusion of children in representative processes. Secondly, it maintains that children's present interests share certain contents with the interests they will share in the long term with the as-yet unborn.

\section{The Juridical All-Affected-Interests Principle}

Representative action involves identifying and qualifying the representatives and the normative principles that guide their actions. Given the constitutive nature of political representation, it is also paramount that the represented can be easily identified. Typically, in representative democracies, the class of the represented is straightforwardly called 'the people' or 'the constituency'. The problem of identifying the represented is therefore connected to the problems of membership of a people. This is hardly the same as inquiring about enfranchisement since the class of the represented does not have to coincide with the electorate. Those who participate in the franchise automatically acquire the status of being represented in the operation of representative government, but that does not mean that representative government only represents members of the franchise. An effective politics of inclusion attributes a high degree of importance to the possibility of asymmetry between the represented and the franchise: a democracy is more inclusive if the people granted the right to participate in collective decisions coincide with the people ruled by those decisions (Held 1996, 335). But the existence of an asymmetry does not overrule the conceptual distinction between the represented and the franchise.

The distinction is highlighted by recourse to the all-affected-interests principle, according to which 'everyone who is affected by the decisions of a government should have a right to participate in that government' (Dahl 1970, 64). This right can be understood as a right to vote - that is, a right of membership of the franchise, in the sense that 'what touches all should be decided by all' (Waldron 1999, 110). But it can also be understood simply as a right to be represented. A basic condition for being included in representative processes would be that a person is 'affected' by the decisions enacted by the representatives (Dryzek 2002; Katz 1997, 217; Young 2000, 6). Such a right would imply a duty on the part of representatives to take account of the affected interests in the representative action, regardless of the problem of membership of the franchise. In this latter sense, the all-affected-interests principle would allow the inclusion of any kind of stakeholders.

\footnotetext{
${ }^{6}$ The most notorious experiences heretofore are the Israeli Commissioner for Future Generations, the Hungarian Ombudsman for Future Generations, the Finnish Committee for the Future, and the constitutional provisions in favour of future generations included in the Bolivian, Japanese and Norwegian constitutions. For further information, see Rose (2016b, 227-405). For alternative proposals, see Gónzalez-Ricoy and Gosseries (2016).
} 
The difficulties associated with determining who is 'affected' by public norms and policies, however, also apply to who can be included in the representative action. The particular conception of 'affected' that one embraces ultimately leads to different conclusions about who is considered to be 'affected', for instance regarding whether 'affected' implies a necessary causal relationship or only probabilistic reasoning, what kinds of interests are relevant for ascertaining that one was significantly affected by a collective decision, and whether all stakeholders are equally relevant or only those who share high stakes in a decision. Overall, the principle seems like 'a potential source of ambiguities' (Rubio Marin 1998, 56) that offers a 'diffuse galaxy of uncountable possibilities' (Dahl 1970, 66). Because, in its general outlines, it seems too vague to be of much help, its role in specifying who can be included in the representative action (as represented) needs to be narrowed down.

Regardless of whether being affected requires a causal or probabilistic relationship, not all stakeholders can be politically represented. Otherwise, since 'just about anyone could be affected by just about nothing' (Fraser 2005, 83) and stakeholders could be 'virtually everyone in all possible and future worlds' (Goodin 2007, 55), the representative process would likely suffer from overinclusion. Certain stakeholders simply do not belong in the class of the represented. For instance, collective entities are generally regarded as stakeholders but not as represented. That is why they have advocates lobbying for them vis-à-vis governments rather than governments representing them. And many stakeholders (such as multinational companies, non-governmental organizations, certain ethnic communities, temporary workers, etc.) have a transnational or international nature, which makes it difficult to implement representation at the structural political level.

Moreover, not all stakeholder interests are equally affected. For instance, my interest in preventing the hospital in my neighbourhood from closing down is different from the interests of my children's children, who may never come to exist or live in the vicinity of that hospital. From the viewpoint of inclusion in representative processes, it therefore seems strange that interests that are unequally affected, especially in light of values with varying degrees of (moral) importance, may imply an equal claim to membership of the class of the represented. Acceptance that all affected interests, regardless of their moral status, are relevant for inclusion in representative processes may produce yet another case of overinclusion.

Narrowing the scope of the all-affected-interests principle is paramount for adopting it as a normative standard of inclusion in the representative process. Four additional criteria must be added to stakeholding in order to ascertain inclusion in the class of the represented. What those criteria are based on is the very nature of the representative process.

First, stakeholders have to be existing persons, for all the reasons discussed in the previous section. The representative action is constitutive of the class of the represented in the sense that it brings forth a new entity (the represented) that shapes previously existing entities as political agents. But something can be 're-presented' only if it has the means to be 'present' in the first place. Representation is constitutive of a social institutional fact, not of a metaphysical entity.

The second criterion is that the interests at stake have to be reasonably relevant to political action. Those (mostly, but not necessarily, moral) values that justify having representatives in order to be protected and implemented help to determine which interests are relevant in this sense. Fundamental rights and the preservation of life are good examples of values that call for representative political action. Economic values can also pass the test of political relevance, especially if they relate to assuring the quality of life. Ultimately, the yardstick determining reasonable political relevance coincides with the reasons for instituting political representation.

Thirdly, stakeholders must be able to acquire a normative status in the representative process. They must become rights and/or duty bearers as a result of the representative relationship. The represented, as such, have claim-rights vis-à-vis their representatives that induce them to stand for their interests, irrespective of the content of the mandates, that is, irrespective of whether the representatives represent their actual interests or only their best interests. Similarly, since the representative action is intended to produce norms and policies, the represented are also 
supposed to be bound by the collective decisions in which their representatives participate. This double-edged normative relationship, from the viewpoint of the represented, limits the circle of relevantly affected individuals to those who are the addressees of representative government. What ultimately justifies their inclusion in democratic representative processes is the fact that they are subjects. However, they are not subjects in the sense that political power shapes their behaviour, but in the sense that the product of the representative action turns them into duty bearers. Being affected by the decisions of a political organization is fundamentally different from being governed by the norms and policies enacted by that political organization; anybody can be affected by the coercive actions and decisions of government authorities. The crucial point is not whether a person has been forced to comply with a particular precept, but that each subject is obliged to comply with the complex normative system that stems from the representative action.

Fourthly, stakeholders have to be human. This seemed like a self-evident truth throughout several centuries of the history of political thought. But it must be reasserted in the wake of the recent debates on political representation that accept companies, animals or the Earth within the class of the represented. The reason why they must be human follows from the previous basic tenets of representation. Animals and natural objects do not fall under the definition of existent entities capable of being rights and duty bearers inside and due to the representative relationship. Furthermore, the interests of collective entities do not relate to fundamental values directly but only instrumentally, to the extent that the purpose of such collective entities is to serve the interests of their human members. Collective entities can only exist and act via human agents, and thus would need to be already represented by someone in order to enter into a subsequent relationship of political representation. At this level, the distinction between lobbying and representing remains justified. Whereas the former gives voice to any interests, only the latter gives a political voice to those whose interests matter the most - human persons.

Together, the four criteria boil down to the juridical all-affected-interests principle. ${ }^{7}$ Represented are all existing humans whose reasonably relevant interests are affected by normative decisions of which they are the addressees.

\section{Applying the Juridical All-Affected-Interests Principle to Children}

A stringent application of the juridical all-affected-interests principle may be detrimental to the inclusion of future persons and children in political representation. On the one hand, the as-yet unborn do not exist, so they are presently neither rights-holders nor duty bearers. On the other hand, children seem to lack the cognitive capacity to either exercise the power that needs to be attached to a claim for it to qualify as a right, or to develop the practical reasoning necessary to comply with established norms and policies. However, there are strategies to overcome these exclusions. For instance, the as-yet unborn usually require elaborate metaphysical arguments such as eternalism (Griffith 2017) and a present-rights-of-future-persons view of human rights (Elliot 1989; Schlossberger 2008, 216-233), whereas there seem to be less sophisticated ways of considering children 'affected'.

Two strong arguments support the claim that children are affected by representative action: the argument from subjection and the argument from citizenship. The first is that children are addressees of norms and policies in the indirect sense of being subject to institutions that are authorized to exercise coercion over them or other persons because of them. This argument focuses on the scope of political action from the viewpoint of legal institutions. Typically, that scope is defined in terms of territoriality, but in this case, the standard for measuring the legal scope is normative rather than territorial. The addressees of such norms and policies directed at institutions designed to protect children are the officials of those institutions. They are either

${ }^{7}$ Sometimes alternatively labeled 'the all-subjected principle' (Näsström 2011; Owen 2012). 
bound by legal injunctions or authorized by power-conferring norms to exercise discretion in creating further children-protecting norms. The efficacy of child-protecting norms, however, whether duty conferring or power conferring, depends on children being affected by the implementation of the contents of such norms. Children thus indirectly become legal subjects.

The second argument is that children have a juridical personality entitling them to become agents in normative relations - including citizenship rights. Will-theorists of rights object to this position. Unlike interest-theorists of rights, who view the function of rights as to protect significant interests, will-theorists see rights as zones of freedom to be granted only to those able to exercise the powers to waive and to seek enforcement of the relevant claims. According to this view, children do not have rights, strictly speaking, even though they still have interests that can be protected by granting rights directly to those who are able to exercise powers associated with the relevant claims - their parents or guardians (Kramer 2001, 30). Interest-theorists, however, are able to incorporate the will into their views. They maintain that the will may be an important sign of interest (MacCormick 1976,315) and that a higher-order interest in freedom is satisfied only when the will is satisfied (Sumner 1987, 47). Interest-theorists and will-theorists alike endeavour to attain the best possible account of what should be regarded as rights, and of what their function should be. But both seem to acknowledge, at least implicitly, that the truth about rights is somewhere in between.

One way to reconcile both positions is to understand rights as grounded in some sort of interest or will. A duty would arise toward some person if it favoured her interest or will - that is, if it favoured both that person's interest and her will if they coincided, and either her interest or her will if they differed (depending on what should be given precedence in each situation). However, this concept still seems to fall short of successfully identifying what is common to interests and wills in relation to rights.

Personal value might be a useful alternative. According to this notion, the personal value of a state of affairs $\mathrm{X}$ related to a person $\mathrm{P}$ is constituted by the reasons to favour or disfavour that state of affairs X for the sake of that person P (Rønnow-Rasmussen 2011, 47). Interest and will can play a part in this notion. When someone's interest or will constitutes a reason for one to act, one has a reason to act for that person's sake. However, personal value is to be understood differently from both interest and will. A person's interest may be what is good for her, whereas personal value is what may be good because of her - that is, what everyone has reason to want for her sake. And personal value is not necessarily what a person values or takes to be valuable by her will, given that such subjective stances can be outweighed by other reasons to act for the sake of that person. ${ }^{8}$

These two alternatives come together in the notion of juridical personality. All children have personal value and certain interests, and many have a minimum capacity for practical deliberation in terms of expressing will. Their normative status is not circumscribed by a legal threshold beyond which they have rights and before which they have no rights. Rather, their right holding is a multi-model status: the capacity for rights is different from the capacity for acts. To say that a person has a capacity for rights is merely to say that she is a person and that others are bound to treat her as a person; the capacity for acts refers to a person's power or ability to directly cause normative consequences through her acts and conduct. A person can then have a capacity for right $\mathrm{R}$ at a moment $t_{1}$ and only acquire the capacity to act associated with $\mathrm{R}$ at a subsequent moment $t_{2}$. Between $t_{1}$ and $t_{2}$, R will have to be exercised via someone else. In private relations, parents and guardians can fulfil that role. But in the public sphere, elected officials can fulfil the same role in a much more efficient way (Campos 2019a).

Even though the argument from citizenship is different from the argument based on subjection, a similar multi-point model is expressed in children's duty bearing. Infants are utterly

\footnotetext{
${ }^{8}$ I derive this approach to rights as 'interest or will' or 'personal value' from my fruitful discussions with Pedro Múrias (2018), whom I thank.
} 
incapable of being under an obligation, because being bound by norms requires a minimum aptitude for reasoning. But most children who are no longer infants have already developed a sense of right and wrong that allows them to grasp what it means to be obligated to something. That many children are indeed capable of being addressees of commands and injunctions is evinced in the fact that many jurisdictions attribute some level of legal liability (even in negligence) to them for certain wrongful acts. The degree of reasonable care to be expected of a child depends on their age and experience. Children's liability is assessed differently in some respects from how an adult's wrongdoing would be assessed. The test is whether or not a child has exercised the care expected from children of a similar age and experience. The closer the child is to the age of majority, the more the standard of care expected of her resembles that of an adult. Liability is not decided in an all-or-nothing fashion; it is determined in degrees, based on a case-by-case assessment of how the child is capable of exercising her potential to reason from norms. The legal capacity for being bound by norms and policies is inherent in the status of an individual's legal personality acquired at birth. But the legal capacity to exercise the reasoning required by norms and policies only manifests itself once the child begins to acquire a perception of how one becomes obligated to something.

If children are indeed subjects of norms and policies and their interests are 'affected' in every relevant sense of the word, their subjection and citizenship status should be reflected in the representative process. They are members of the class of the represented even if they are not recognized with a membership of the franchise. However, this still falls short of demonstrating that democracies incorporate the instruments to protect the interests of as-yet unborn persons. At most, it supports the claim that they incorporate the instruments to protect the interests of children. In order to make the distant future enter the equation, one further argument is needed.

\section{The Semi-Future Constituency}

Debates about whether the as-yet unborn may be included in representative processes often strive to circumvent the political privilege of the present, for instance by asserting that existence is not dependent upon presentism, the view that only present states of affairs exist. Within this frame of reference, relating the present to the distant future consists of connecting two different kinds of existence rather than comparing a state of affairs that exists with a state of affairs that does not exist. Both those who think that we will always affect future generations (Kumar 2018; Rose 2016a) and those who think that we never affect future generations in the long run (Tännsjö 2006) discriminate between the present as one form of existence and the future as a different form of existence.

This setting follows from a conception of time that encompasses the past, the present and the future. Suppose time can be established in a linear manner. Now suppose a snapshot of a present moment $t_{1}$ and a subsequent snapshot of a future moment $t_{2}$. Concerns over affecting future persons who exist at the future moment $t_{2}$ are normatively relevant at the present moment $t_{1}$. The relationship between $t_{1}$ and $t_{2}$ typifies a present-future kind of temporal order. The problem seems to be the difficulty of representing politically at $t_{1}$ what exists solely at $t_{2}$. Strategies that favour some form of political inclusion of the as-yet unborn try to establish a normative criterion at $t_{1}$ (such as a broad version of the all-affected-interests principle) in light of which interests or rights existing solely at $t_{2}$ will be relevant already at $t_{1}$. The standard established at $t_{1}$ applies to existents at $t_{1}$ because members of $t_{2}$ already fall under the purview of the same standard at $t_{1}$.

The whole argument about the political inclusion of the as-yet unborn relies on the assumptions that (1) there will be persons in a future time $t_{2}$; (2) those persons are likely to be affected by actions, norms and policies developed at a present time $t_{1}$; and (3) they fall under the purview of the normative criterion for political inclusion binding at $t_{1}$. These assumptions are descriptive of the state of affairs of $t_{2}$ from the viewpoint of $t_{1}$. For the purposes of political representation, it is irrelevant whether the states of affairs of $t_{2}$ actually occur at $t_{2}$ as was assumed at $t_{1}$. For instance, 
there may be persons at $t_{2}$ who are unaffected by any actions practised at $t_{1}$. Alternatively, those persons at $t_{2}$ may endorse criteria of political inclusion unbeknownst at $t_{1}$; or there may not even be any persons at all at $t_{2}$. In such cases, if those three assumptions are stated at $t_{2}$ to describe the reality of $t_{2}$, they are false. But it is not possible that such assumptions concerning the states of affairs of $t_{2}$ are not considered true at $t_{1}$. That is what justifies accepting or rejecting the inclusion of the as-yet unborn in representative processes. The fact that the same statements about $t_{2}$ can be true at $t_{1}$ and perhaps false at $t_{2}$ means that such statements are subject to different truth conditions depending on when they are stated.

The distinction between truth conditions at $t_{1}$ and $t_{2}$ expresses an epistemic difference between the present and the future. Within this present-future kind of temporal order, the future comprises the set of all intervals (including $t_{2}$ ) beginning immediately after $t_{1}$ and extending into the indefinite interval. What is true at $t_{1}$ is true only at $t_{1}$ as actual, regardless of the future and independently of any additional elements at any interval. The moment immediately succeeding $t_{1}$ in the order of time can reproduce the same characteristics of $t_{1}$. Still, it will be subject to truth conditions that are not necessarily the same as those of $t_{1}$.

This present-future divide that predominantly contextualizes the debates on the representation of the future is, however, inadequate from the moment that representative processes take in children of all ages. Children have personal value in the present qua persons. With such status, they are equally citizens and subject to the law at $t_{1}$. But they also have personal value in the present qua children. This means that they have specific interests and needs in the present that differ from the interests and needs of adults. ${ }^{9}$ But it also means that they have present interests in acquiring the status that allows them to hold and exercise their rights and duties fully - that is, special present interests in future states of affair that concern them directly. For instance, they have interests that their present capacity for rights will develop into a future capacity for exercising those rights. Their interests at $t_{1}$ encompass a multitude of present possibilities (such as additional right bearing and duty following) that are to be realized only at any set of intervals between $t_{1}$ and $t_{2}{ }^{10}$

In this new setting, the temporal order no longer displays a clear-cut distinction between the present and the future, but a sort of 'semi-future conception of the present' (Lewis 1973, 105) that comprises the set of all intervals beginning at $t_{1}$ and including $t_{1}$ itself, as though the present were the first moment of the future. In the semi-future temporal order, if $\mathrm{X}$ is true already at $t_{1}$, then all the succeeding intervals are true at $t_{1}$ if $\mathrm{X}$ is true at $t_{1}$.

In the political realm, this translates into interests and rights held by actual persons at $t_{1}$; correlative norms and policies will protect interests and rights that those persons have at $t_{1}$ and at any succeeding moment in which the same persons will continue to exist. Those interests are long-term interests insofar as statements about them are necessarily true ${ }^{11}$ at both $t_{1}$ and at the succeeding intervals, perchance including $t_{2}$. Statements of the kind 'When it is next the case

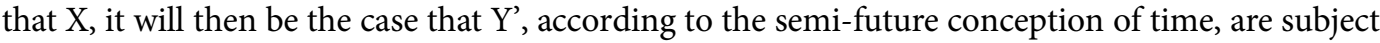
to the same truth conditions with regard to children's interests at both $t_{1}$ and at the succeeding intervals. If children have an interest $\mathrm{X}$ at $t_{1}$ in fulfilling the average life expectancy at birth and of

\footnotetext{
${ }^{9}$ This is the rationale behind the principle included in the Convention on the Rights of the Child, from 1990, that a primary consideration in public policies affecting children should be 'the best interests of the child' (art. 3(I)).

${ }^{10}$ Some authors understand these interests in terms of rights under the headings of 'anticipatory autonomy rights' (Feinberg 1980) or 'developmental rights' (Eekelaar 1986), that is, rights attributed to a person because of the adult she will become. The protection of such rights ensures that, as an adult, the child will be in a position to exercise her citizenship rights to the maximal or at least to a very significant degree. They therefore impose duties on the state to protect these rights. For democratic representation, though, such interests do not have to be conceived in terms of rights existing prior to the representative relationship.

${ }^{11}$ Interests of this sort are objective reasons for willing something. Statements about persons having interests in $\mathrm{X}$ can be true or false depending not on whether those persons in fact want or need X, but on whether such statements express justifications that could be endorsed by anybody in all-things-considered situations.
} 
becoming fully fledged citizens and participants in law making, those interests should be represented politically and protected by some normative instrument $\mathrm{Y}$ at $t_{1}$. The normative instrument $\mathrm{Y}$ that protects them stretches into the future and might still be binding at $t_{2}$ because it partakes in the truth conditions of $t_{1}$.

This temporal strategy for representing children's interests in the long run shows that, at any given moment in time, there is a need to consider the impact of actions, norms and policies for the duration of the remaining lives of existing children. It is not inclusive of the interests of the as-yet unborn. But the interests of future persons can be represented indirectly. The interests of children assessed at $t_{1}$ will be subject to the same truth conditions at $t_{2}$, when members of future generations who were not alive at $t_{1}$ may now exist. If interests held by any persons alive at $t_{2}$ who were not alive at $t_{1}$ coincide with the long-term interests held by children at $t_{1}$, then the representation of the latter interests indirectly brings the former interests to the fore.

Suppose a child $\mathrm{A}$ is born at $t_{1}$. Her present interests include the means to develop the capacity to exercise the rights inherent in her juridical personality fully at any given interval between $t_{1}$ and, for instance, a moment $t_{2}$ in which she will celebrate her eighteenth birthday. These interests provide normative grounds for political representation at $t_{1}$. If another child $\mathrm{B}$ is born in the interval immediately preceding $t_{2}$, her then present interests will have the exact same content as the interests held by $\mathrm{A}$ at $t_{1}$, even if $\mathrm{A}$ at $t_{2}$ no longer has the same interests she had at $t_{1}$. By continuously representing interests with the same content about the long (even if not so distant) term, the interests of B are indirectly taken into account in political processes at $t_{1}$. This falls short of becoming an actual political representation of future persons, but it is a way of including the interests of future persons in a representative democracy.

Consider also a world with three generations (G1, G2, G3), in which G2 overlaps with both G1 and G3 but in which G1 never overlaps with G3. At $t_{1}$, G2 is comprised mostly of children. The representation of the interests of G2 requires that G1 represents at $t_{1}$ interests that coincide with those held by members of G3 at $t_{2}$. The interests calling for representation by G1 are held by members of G2 at $t_{1}$, and these interests include at $t_{1}$, for instance, an interest in fulfilling the life expectancy at birth with quality and equal political participation, which entails a present expectation of overlapping coexistence with members of G3 at $t_{2}$. Since human population replacement is continuous rather than proceeding in a step-by-step fashion (Barry 1977, 268; Scheffler 2018, 15-16), the interests of any persons born at $t_{1}$ comprehend a considerable regard for succeeding moments. This does not require a political relationship between members of G1 and G3, either at $t_{1}$ or at $t_{2}$; but the nature of the representative relationship between members of G1 and G2 at $t_{1}$ is based upon an interest X that includes the expectation that members of G2 will be alive at $t_{2}$ enjoying the same capacities that members of G1 enjoyed at $t_{1}$. The reason for this equality of treatment is that $\mathrm{X}$ is equally true at $t_{1}$ and at every single moment between $t_{1}$ and $t_{2}$. Interests and representation between members of different generations are therefore continuously ongoing and actual.

Certain strategies of generational overlap take the interests of remote future generations into consideration either by granting to G2 at $t_{1}$ a right to defend the interests of G3 or by claiming that G2 has an interest in fulfilling its duties to G3 and therefore a corresponding interest in preventing G1 from making it harder for G2 to comply with these duties (Gosseries 2008b, 461-464). But these strategies seem to confuse temporal orders, given that at $t_{1}$ the interests of G3 exist only as interests of G2, which are at $t_{1}$ the present interests of G2 concerning the future. For those strategies, however, the interests of G3 at $t_{1}$ exist for G1 qua future, not qua semi-future. The only way to overcome this difficulty is to narrow the temporal scope even further - that is, by binding members of G1 to the interests of persons who actually overlap with them at $t_{1}$, rather than with those with whom they shall overlap eventually. Since these interests necessarily belong to members of G2 at $t_{1}$ who become also members of G1 at $t_{2}$, the interests of G3 are relevant only as interests of $\mathrm{G} 2$ that are to become G1. 
This argument might help to justify actions, norms and policies today that protect the interests of people who will live very far in the future, even if they are not made or established for that specific purpose.

\section{Conclusion}

Even though there is no such thing as political representation of future persons, the interests of the as-yet unborn can still be included in representative processes without having to appeal to alternative conceptions of representation. The key to achieving that aim is to include children in the representative action, not so much at the level of the franchise, but mostly at the level of the exercise of representative government. The representation of children as members of the constituency at a present moment $t_{1}$ voices interests that are similar to the interests held by those who live at a future moment $t_{2}$. The latter interests are therefore voiced indirectly in the operation of representative action at $t_{1}$. Overall, what is required for the representation of relevant affected interests that will be held by as-yet unborn persons is an optimal operation of representative democracy whereby the represented are voiced, including children of all ages as a special case of semi-future citizens.

\section{References}

Agius E and Busuttil S (eds) (1998) Future Generations and International Law. London: Earthscan.

Attfield R (2003) Environmental Ethics. Cambridge: Polity Press.

Barry B (1977) Justice between generations. In Hacker PSM and Raz J (eds), Law, Morality and Society. Oxford: Clarendon Press, pp. 268-284.

Beckman L and Uggla F (2016) An ombudsman for future generations: legitimate and effective? In Gosseries A and González-Ricoy I (eds), Institutions for Future Generations. Oxford: Oxford University Press, pp. 117-134.

Beyleveld D, Düwell M and Spahn A (2015) Why and how should we represent future generations in policymaking? Jurisprudence 6, 549-566.

Bidadanure J (2016) Youth quotas, diversity, and long-termism. Can young people act as proxies for future generations? In Gosseries A and González-Ricoy I (eds), Institutions for Future Generations. Oxford: Oxford University Press, pp. 266-281.

Bovenkerk B (2015) Public deliberation and the inclusion of future generations. Jurisprudence 6(3), 496-515.

Campos AS (2019a) Infant political agency. Redrawing the epistemic boundaries of democratic inclusion. European Journal of Political Theory. doi: 10.1177/1474885119874341.

Campos AS (2019b) The rights of future persons under attack: correlativity in the non-identity problem. Philosophia 47(3), 625-648.

Caney S (2016) Political institutions for the future: a fivefold package. In Gosseries A and González-Ricoy I (eds), Institutions for Future Generations. Oxford: Oxford University Press, pp. 135-155.

Carstensen L, Isaacowitz DM and Charles ST (1999) Taking time seriously: a theory of socioemotional selectivity. American Psychologist 54(3), 165-181.

Cook P (2013) Against a minimum voting age. Critical Review of International Social and Political Philosophy 16(3), 439-458.

Dahl R (1970) After the Revolution. New Have CT: Yale University Press.

Dobson A (1996) Representative democracy and the environment. In Lafferty W and Meadowcroft J (eds), Democracy and the Environment. Cheltenham: Elgar, pp. 124-139.

Dryzek J (2002) A post-positivist policy-analytic travelogue. The Good Society 11, 32-36.

Eckersley R (2011) Representing nature. In Alonso S, Keane J and Merkel W (eds), The Future of Representative Democracy. Cambridge: Cambridge University Press, pp. 236-257.

Eekelaar J (1986) The emergence of children's rights. Oxford Journal of Legal Studies 6, 161-182.

Ekeli KS (2005) Giving a voice to posterity - deliberative democracy and representation of future people. Journal of Agricultural and Environmental Ethics 18, 429-450.

Ekeli KS (2006) The principle of liberty and legal representation of posterity. Res Publica 12, 385-409.

Ekeli KS (2009) Constitutional experiments: representing future generations through submajority rules. The Journal of Political Philosophy 17(4), 440-461.

Elliot R (1989) The rights of future persons. Journal of Applied Philosophy 6, 159-169.

Feinberg J (1980) A child's right to an open future. In Aiken W and LaFollette H (eds), Whose Child? Parental Rights, Parental Authority and State Power. Totowa: Littlefield, Adams and Co., pp. 124-153.

Fraser N (2005) Reframing justice in a globalizing world. New Left Review 36, 69-88. 
González-Ricoy I and Gosseries A (eds) (2016) Institutions for Future Generations. Oxford: Oxford University Press.

Goodin RE (1996) Enfranchising the earth, and its alternatives. Political Studies 44(5), 835-849.

Goodin RE (2007) Enfranchising all affected interests, and its alternatives. Philosophy and Public Affairs 35(1), 40-68.

Göpel M (2012) Ombudspersons for Future Generations as Sustainability Implementation Units. London: Stakeholder Forum.

Gosseries A (2008a) Constitutions and future generations. The Good Society 17(2), 32-37.

Gosseries A (2008b) On future generations' future rights. The Journal of Political Philosophy 16, 446-474.

Green L, Fry AF and Myerson J (1999) Discounting of delayed rewards across the life span: age differences in individual discounting functions. Behavioural Processes 46, 89-96.

Griffith AA (2017) The rights of future persons and the ontology of time. Journal of Social Philosophy 48, 58-70.

Held D (1996) Models of Democracy. Cambridge: Polity Press.

Heyward C (2008) Can the all-affected principle include future persons? Green deliberative democracy and the non-identity problem. Environmental Politics 17(4), 625-643.

Hinrichs K (2002) Do the old exploit the young? Is enfranchising children a good idea? European Journal of Sociology 43, 35-58.

Karnein A (2016) Can we represent future generations? In Gosseries A and González-Ricoy I (eds), Institutions for Future Generations. Oxford: Oxford University Press, pp. 83-97.

Katz R (1997) Democracy and Elections. New York: Oxford University Press.

Kavka G and Warren V (1983) Political representation for future generations. In Elliot R and Gare A (eds), Environmental Philosophy. Milton Keynes: Open University Press, pp. 20-39.

Kramer M (2001) Getting rights right. In Rights, Wrongs and Responsibilities. Basingstoke: Palgrave, pp. 28-95.

Kumar R (2018) Risking future generations. Ethical Theory and Moral Practice 21(2), 245-257.

Lefort C (1988) Democracy and Political Theory. Oxford: Polity.

Lewis D (1973) Counterfactuals. Oxford: Blackwell.

MacCormick N (1976) Children's rights: a test-case for theories of right. Archiv für Rechts- und Sozialphilosophie 62(3), 305-317.

MacKenzie MK (2016) A general-purpose, randomly selected chamber. In Gosseries A and González-Ricoy I (eds), Institutions for Future Generations. Oxford: Oxford University Press, pp. 282-298.

Mansbridge J (2003) Rethinking representation. American Political Science Review 97(4), 515-528.

Múrias P (2018) Personal value in the analysis of rights. Católica Law Review 2(2), 25-40.

Näsström S (2011) The challenge of the all-affected principle. Political Studies 59(1), 116-134.

Niemeyer S and Jennstål J (2016) The deliberative democratic inclusion of future generations. In Gosseries A and González-Ricoy I (eds), Institutions for Future Generations. Oxford: Oxford University Press, pp. 247-265.

Owen D (2012) Constituting the polity, constituting the demos: on the place of the all affected interests principle in democratic theory and in resolving the democratic boundary problem. Ethics and Global Politics 5(3), 129-152.

Palsson AM (1996) Does the degree of relative risk aversion vary with household characteristics? Journal of Economic Psychology 17(6), 771-787.

Parfit D (1987) Reasons and Persons. Oxford: Clarendon Press.

Parijs PV (1998) The disfranchisement of the elderly, and other attempts to secure intergenerational justice. Philosophy and Public Affairs 27(4), 292-333.

Pitkin HF (1967) The Concept of Representation. Berkeley: University of California Press.

Read R (2012) Guardians for the Future. [n.p.]: GreenHouse Report.

Rehfeld A (2006) Towards a general theory of political representation. The Journal of Politics 68(1), 1-21.

Ringen S (1997) Citizens, Families and Reform. Oxford: Oxford University Press.

Rønnow-Rasmussen T (2011) Personal Value. Oxford: Oxford University Press.

Rose M (2016a) Constitutions, democratic self-determination and the institutional empowerment of future generations: mitigating an aporia. Intergenerational Justice Review 9(2), 56-71.

Rose M (2016b) Zukünftige Generationen in der heutigen Demokratie. Dordrecht: Springer.

Rubenstein J (2007) Accountability in an unequal world. The Journal of Politics 69(3), 616-632.

Rubio Marin R (1998) National limits to democratic citizenship. Ratio Juris 11(1), 51-66.

Saward M (2009) Authorization and authenticity: representation and the unelected. The Journal of Political Philosophy $17,1-22$.

Scheffler S (2018) Why Worry About Future Generations? Oxford: Oxford University Press.

Schlossberger E (2008) A Holistic Approach to Rights. Lanham, MD: University Press of America.

Schmitt C (2008) Constitutional Theory. Durham, NC: Duke University Press.

Slaughter RA (1994) Why should we care for future generations now. Futures 26(10), 1077-1085.

Stein T (1998) Does the constitutional and democratic system work? The ecological crisis as a challenge to the political order of constitutional democracy. Constellations 4, 420-449.

Steinberg L et al. (2009) Age differences in future orientation and delay discounting. Child Development 80(1), 28-44.

Sumner LW (1987) The Moral Foundations of Rights. Oxford: Oxford University Press.

Tännsjö T (2006) Cosmopolitan democracy revisited. Public Affairs Quarterly 20(3), 267-291. 
Thompson D (2010) Representing future generations: political presentism and democratic trusteeship. Critical Review of International Social and Political Philosophy 13(1), 17-37.

Tonn B and Hogan M (2006) The House of Lords: guardians of future generations. Futures 38, 115-119.

Umbers LM (2018) Enfranchising the youth. Critical Review of International Social and Political Philosophy. doi: 10.1080/ 13698230.2018 .1511172$.

Urbinati N (2000) Representation as advocacy: a study of democratic deliberation. Political Theory 28(6), 458-786.

Urbinati N (2006) Representative Democracy: Principles and Genealogy. Chicago, IL: University of Chicago Press.

Urbinati N and Warren $\mathbf{M}$ (2008) The concept of representation in contemporary democratic theory. Annual Review of Political Science 11, 387-412.

Waldron J (1999) Law and Disagreement. Cambridge: Cambridge University Press.

Wall J (2014) Why children and youth should have the right to vote: an argument for proxy-claim suffrage. Children, Youth and Environments 24(1), 108-123.

Weiss EB (1992) In fairness to future generations and sustainable development. American University International Law Review 8(1), 19-26.

Young IM (2000) Democracy and Inclusion. Oxford: Oxford University Press.

Cite this article: Campos AS (2021). The British Academy Brian Barry Prize Essay: Representing the Future: The Interests of Future Persons in Representative Democracy. British Journal of Political Science 51, 1-15. https://doi.org/10.1017/ S000712341900067X 